\title{
STRUKTUR KOMUNITAS MANGROVE DI DESA TEWE, KECAMATAN JAILOLO SELATAN, KABUPATEN HALMAHERA BARAT PROVINSI MALUKU UTARA
}

\author{
Nebuchadnezzar Akbar ${ }^{1}$, Abjan Ibrahim ${ }^{1}$, Irfan Haji ${ }^{2}$, Irmalita Tahir ${ }^{1}$, \\ Firdaut Ismail ${ }^{1}$, Muhajirin Ahmad ${ }^{1}$, Raismin Kotta ${ }^{2}$ \\ ${ }^{1}$ Program Studi IImu Kelautan, FPIK. Universitas Khairun Ternate \\ ${ }^{2}$ Lembaga Ilmu Pengetahuan, Ternate \\ E-mail:nezzarnebuchad@yahoo.co.id
}

Received March 2018, Accepted April 2018

\begin{abstract}
ABSTRAK
Ekosistem mangrove merupakan habitat hidup serta tempat berkembang bagi biota bentik dan ikan. Aktivitas dikawasan pesisir desa Tewe sangat tinggi, sehingga memberikan dampak pada ekosistem mangrove. Pemanfaatan tidak berkelanjutan memberikan pengaruh terhadap jumlah dan sebaran mangrove. Informasi tentang nilai ekologi mangrove sangat penting, guna memberikan gambaran kondisi mangrove saat ini. Pengambilan contoh mangrove, di lakukan dengan menggunakan metode transect quadrant dan spot check. Hasil penelitian diperoleh ketebalan hutan mangrove dikawasan Desa Tewe berdasarkan pengamatan adalah 412 meter (Stasiun I), 389 meter (Stasiun II), 367 meter (Stasiun III). Komposisi jenis hutan mangrove dari hasil pengamatan dan identifikasi diperoleh sebanyak 9 jenis dari 5 famili. Hasil analisis menunjukan struktur komunitas hutan mangrove di Desa Tewe berdasarkan indeks ekologi (nilai kerapatan, frekuensi jenis, tutupan dan nilai penting) baik, sedangkan keanekaragaman spesies masngrove termasuk dalam kategori sedang. Akan tetapi aktivitas pemanfaatan perlu mendapatkan perhatian khusus, sehingga kelestarian dan kehadiran mangrove tetap terjaga. Selain itu perlu suatu pendekatan pada masyarakat untuk membantu memberikan informasi terhadap peran, manfaat dan juga strategi pengelolaan serta pelestarian mangrove kedepan.
\end{abstract}

Kata kunci : Desa Tewe, indeks ekologi, ekosistem mangrove, spot check, transect quadrant

\section{ABSTRACT}

Mangrove forest is habitat and nursery ground for fish and marine bentic. Human activities are increasing in coastal area of Tewe village, so that extend impact in mangroves. The unsustainable mangrove exploitation 
influences distribution and quantity of mangroves. Information about mangroves index ecology is important to describe mangroves condition. Transect quadrant and spot check method were used in this study. The results showed that mangroves thickness between 412 meters (station I), 389 meters (station II) and 367 meters (station III). Mangrove composition was found 9 species from 4 families. The ecology index (density, frequency, persent cover and value significant) were chategoryzed into good condition, whereas mangrove biodiversity was chategoryzed into medium. Exploitation in mangrove needs special attention in order to sustainability of mangrove.

Keywords : Ecology index, mangroves forest, Tewe, transect quadrant, spot check

\section{PENDAHULUAN}

Desa Tewe secara administrasi masuk dalam Kecamatan Jailolo Selatan, Kabupaten Halmahera Barat. Desa ini menyediakan tiga ekosistem pesisir dan laut yakni ekosistem mangrove, lamun dan terumbu karang. Ketersediaan ekosistem mangrove tentunya dapat mempengaruhi ketersediaan sumberdaya ikan, komunitas biota bentik dan menciptakan mata rantai didaerah sekitar.Secara umum diketahui bahwa fungsi utama ekosistem mangrove sebagai penyediaan bahan organik, tempat asuhan (nursery ground), tempat bertelur (spawning ground), dan tempat berlindung berbagai biota laut, serta sebagai pelindung pantai dari aktivitas gelombang (Saru, 2009).Selain itu hutan mangrove mempunyai peranan dalam ekosistem yang berfungsi sebagai pelindung terhadap hempasan gelombang dan arus (Tarigan, 2008).

Kawasan pesisir Kabupaten Halmahera Barat memiliki keanekaragaman mangrove yang tinggi ini berdasarkan hasil penelitian yang dilakukan di Pulau Sidangoli pada tiga lokasi yakni Desa Dehe, Gam dan Manomadehe (Yunus, 2005; dan Asman, 2007). Bappedas (2010) melaporkan total luas area ekosistem mangrove di Kabupaten Halmahera Barat adalah 1.971,88ha. Informasi ekosistem mangrove dikawasan pesisir Halmahera Barat juga dilaporkan LIPI (2015) di Pulau Manomadehe, Sidangoli yang menunjukan bahwa ekosistem mangrove memiliki persentase tutupan sangat baik. Penelitian juga dilakukan Akbar et al (2015) di kawasan pesisir Sidangoli, Hamahera Barat berdasarkan tingkat kepadatan ekosistem mangrove masuk dalam kategori rendah.Selain itu. Laporan lainnya Akbar et al (2016) menemukan bahwa terdapat 12 jenis dengan indeks ekologi tergolong cukup baik di Desa Tewe, Kabupaten Halmahera Barat. Berbagai laporan diatas belum memberikan informasi secara keseluruhan tentang kondisi kesehatan mangrove khususnya yang berkaitan dengan stuktur komunitas di Desa Tewe, sehingga perlu adanya penelitian terkait di lokasi ini.

Kehadiran ekosistem mangrove di pesisir Desa Tewe tentunya memberikan gambaran bahwa adanya peluang untuk dikembangkan 82 
daerah ini menjadi tempat wisata alam berbasis ekologi. Penelitian berkaitan dengan status kesehatan hutan mangrove penting dilakukan, karena dapat memberikan gambaran kondisi terkini dan dijadikan basis data pengelolaan mangrove

\section{MATERI DAN METODE}

\section{Lokasi Sampling}

Penelitian dilaksanakan pada bulan Oktober-November 2017 di Desa Tewe, Kabupaten Halmahera Barat. Provinsi Maluku Utara (Gambar 1). Tahapan penelitian dimulai survey awal, pengambilan data lapang, tabulasi data, analisis dan pembuatan laporan.

\section{Teknik Pengambilan Data}

Pengambilan data dilakukan pada 3 stasiun penelitian yakni bagian utara, selatan dan timur. Sampling mangrove menggunakan metode transect quadrant (Bengen, 2004). Pada setiap stasiun transek di tarik tegak lurus dari arah laut ke darat sepanjang 50 meter sebanyak 3 lintasan dengan jarak antara lintasan 20 meter. Pada setiap transek, data vegetasi di cuplik dengan menggunakan 3 kuadrat yang berdekatan (10 m x $10 \mathrm{~m}$ ) dan dalam kuadrant tersebut di susun 4 kuadrat ( $5 \mathrm{~m} \times 5 \mathrm{~m}$ ) untuk pengamatan anakan dan 10 kuadrat kecil $(1 \mathrm{~m} \times 1 \mathrm{~m})$. Pengambilan contoh mangrove juga dilakukan dengan menggunakan metode "spot check", untuk melengkapi informasi komposisi jenis, distribusi jenis, dan kondisi umum ekosistem mangrove yang tidak teramati pada metode transek-kuadrat. Metode ini dilakukan dengan cara mengamati dan memeriksa zona-zona tertentu dalam ekosistem mangrove yang memiliki ciri khusus.

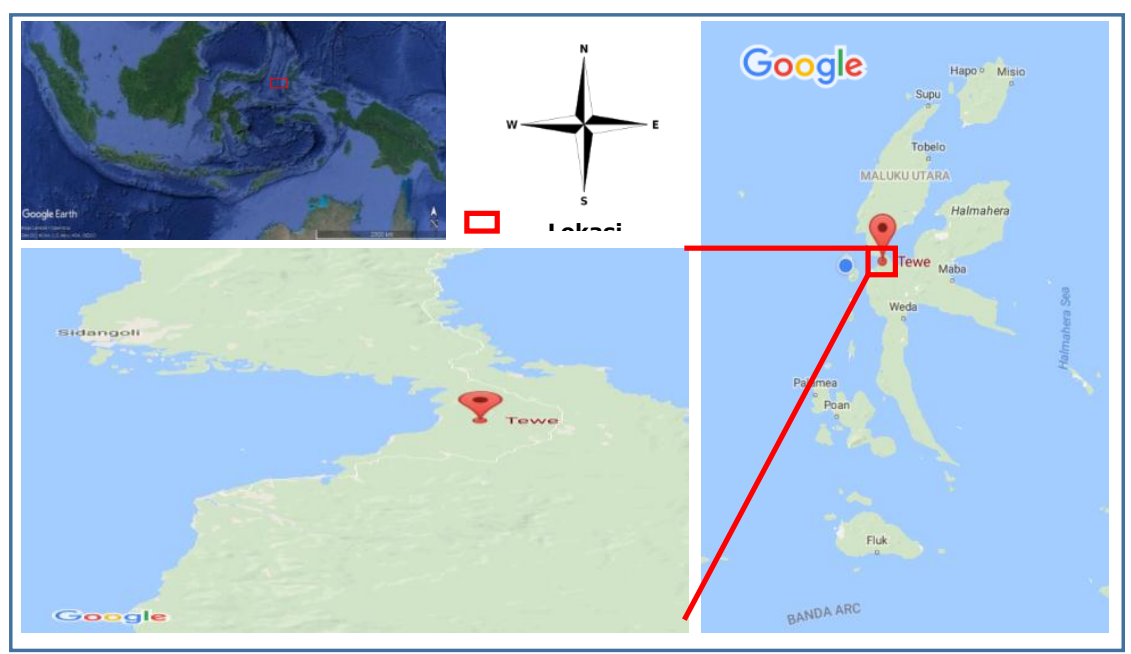

Gambar 1. Lokasi Pengambilan Data Hutan Mangrove 
Data hasil pengambilan mangrove kemudian dicatat dan di masukan kedalam tabel pencatat. Pencatatan data sesuai dengan kategori pertumbuhan mangrove yaitu :

- Kategori pohon: diameter batang $>4 \mathrm{~cm}$

- Kategori anakan : diameter $<4 \mathrm{~cm}$ dan tinggi $>1 \mathrm{~m}$

- Kategori semaian : tinggi $<1 \mathrm{~m}$

Untuk keperluan identifikasi vegetasi mangrove di ambil contoh biologis berupa komponen daun, bunga, dan buah serta diukur lingkaran batang setiap pohon mangrove setinggi dada.Identifikasi tumbuhan mangrove berdasarkan pedoman Noor et al (2012).

\section{Analisis Data}

Analisa data yang digunakan untuk menentukan kondisi hutan mangrove dengan menggunakan analisa kerapatan jenis, frekuensi jenis, luas areal penutupan, nilai penting jenis (Bengen, 2004) dan keanekaragaman jenis Indeks Shannon-Winner (Odum 1971; Krebs 1985).

\section{HASIL DAN PEMBAHASAN}

\section{Parameter Lingkungan}

Hasil pengukuran parameter hidrologi menunjukan bahwa lingkungan didaerah tersebut tergolong baik dimana meliputi suhu, salinitas, $\mathrm{pH}$ air dan $\mathrm{pH}$ tanah (Tabel 1).

Tabel 1. Hasil Pengukuran Parameter Lingkungan

\begin{tabular}{cclcc}
\hline No & Lingkungan & Parameter & Nilai & Satuan \\
\hline 1 & Perairan & Suhu & 29 & ${ }^{0} \mathrm{C}$ \\
2 & & Salinitas & 35 & $\%$ oo \\
3 & & Oksigen terlarut & 5,46 & $\mathrm{mg} / \mathrm{l}$ \\
& & (DO) & 7 & - \\
5 & & $\mathrm{pH}$ air & 6.8 & - \\
6 & \multirow{2}{*}{ Tanah } & $\mathrm{pH}$ tanah & - & - \\
\hline
\end{tabular}

Kusmana (1995) mengatakan bahwa pertumbuhan mangrove yang baik memerlukan suhu rata-rata minimal lebih besar dari $20^{\circ} \mathrm{C}$. Suhu merupakan salah satu parameter yang penting bagi keberlangsungan hidup biota laut. Suhu dapat mempengaruhi proses-proses seperti fotosentesis dan respirasi (Aksornkoae, 1993). Kisaran nilai suhu perairan yang sama juga ditemukan Kushartono (2009) di desa Pasar Banggai Kabupaten Rembang, Harahap dan Mahmudi (2014) di pesisir Kecamatan 84 
Gending Kabupaten Probolinggo, kemudian Agustini et al (2016) di desa Kahyapu Pulau Enggno serta Akbar et al (2017) di Teluk Dodinga Kabupaten Halmahera Barat.

Salinitas merupakan faktor penting dalam pertumbuhan, daya tahan dan zonasi spesies mangrove. Nilai salinitas cenderung tinggi karena lokasi penelitian merupakan pulau kecil yang tidak terpengaruh oleh aliran air tawar dari daratan yang dapat menurunkan nilai salinitas. Nilai salinitas menunjukan tidak terdapat perbedaan signifikan antar setiap lokasi. Akbar et al (2017) mengatakan salinitas merupakan faktor penting dalam pertumbuhan, daya tahan dan zonasi jenis mangrove. Sedangkan Muryani (2009) menyebutkan bahwa dari banyak faktor lingkungan, salinitas mempunyai pengaruh besar pada perkembangan hutan mangrove. Menurut Aksornkoae (1993), mangrove biasanya tumbuh subur di daerah estuaria dengan tingkat salinitas antara 10-30 ppt.

Pengukuran $\mathrm{pH}$ tanah dan air menunjukkan semua lokasi termasuk dalam kategori sangat baik. Data yang peroleh, jika dibandingkan dengan standar yang ditetapkan Keputusan Menteri Lingkungan Hidup KEP No. 51/MNLH///2004, berkisar antara 6.5- 8.5 (MNLH, 2004). Laporan Akbar et al (2017) di Teluk Dodinga, Kabupaten Halmahera Barat menemukan bahwa kondisi $\mathrm{pH}$ yang ditemukan sesuai dengan standar baku butu yang ditetapkan. Sedangkan hal yang berbeda ditemukan Setiawan (2013) dimana terjadi pengasaman nilai $\mathrm{pH}$ di esa Tongke-Tongke, Desa Panaikang dan Desa Pasimarannu. Menurut Hakim (2009) dan Setiawan (2013) nilai $\mathrm{pH}$ yang agak masam, dikarenakan adanya perombakan serasah vegetasi mangrove oleh mikroorganisme tanah yang menghasilkan asam-asam organik sehingga menurunkan $\mathrm{pH}$ tanah. Berdasarkan standar baku mutu yang telah ditetapkan, toleransi organisme terhadap $\mathrm{pH}$ air berdasarkan Keputusan Menteri Lingkungan Hidup KEP No. 51/MNLH///2004, berkisar antara 6.5- 8.5 (MNLH, 2004), sehingga dapat disimpulkan bahwa kisaran $\mathrm{pH}$ air yang ada di lokasi pengamatan masih menunjang kehidupan organisme yang ada.

\section{Ketebalan Hutan Mangrove}

Ketebalan hutan mangrove dikawasan Desa Tewe berdasarkan pengamatan adalah 412 meter (Stasiun I), 389 meter (Stasiun II), 367 meter (Stasiun III) (Gambar 3). Keseluruahan hasil pengukuran ketebalan mangrove setiap stasiun menunjukan adadanya perbedaan ketebalan (Gambar 2). Tipe dan geomorfologi pantai dapat memberikan peredaan distribusi ketebalan diantara stasiun penelitian. Sebagaimana dikemukakan Akbar et al (2016) bahwa perbedaan variasi ini diakibatkan karena setiap stasiun memiliki tipe pantai yang berbeda. Wantasen (2002) menjelaskan bahwa pantai yang landai memiliki tingkat keanekaragaman ekosistem mangrove yang tinggi dibandingkan dengan pantai yang terjal. Lebih lanjut Akbar (2015) mengatakan pada daerah yang landai memiliki ruang yang luas untuk ditumbuhi oleh mangrove sehingga distribusi jenis mangrove meluas dan melebar. Lokasi penelitian stasiun I terletak di 
bagian utara pada desa, yang memperoleh pengaruh gelombang, arus dan angin. Pada stasiun II terletak dibagian tengah Desa Tewe yang pada bagian ini hempasan gelombang dan arus sangat rendah. Pada stasiun III memliki kemiripan dengan stasiun I dimana terletak pada bagian selatan sisi desa yang juga berhadapan dengan bagian perairan lepas Pulau Halmahera.

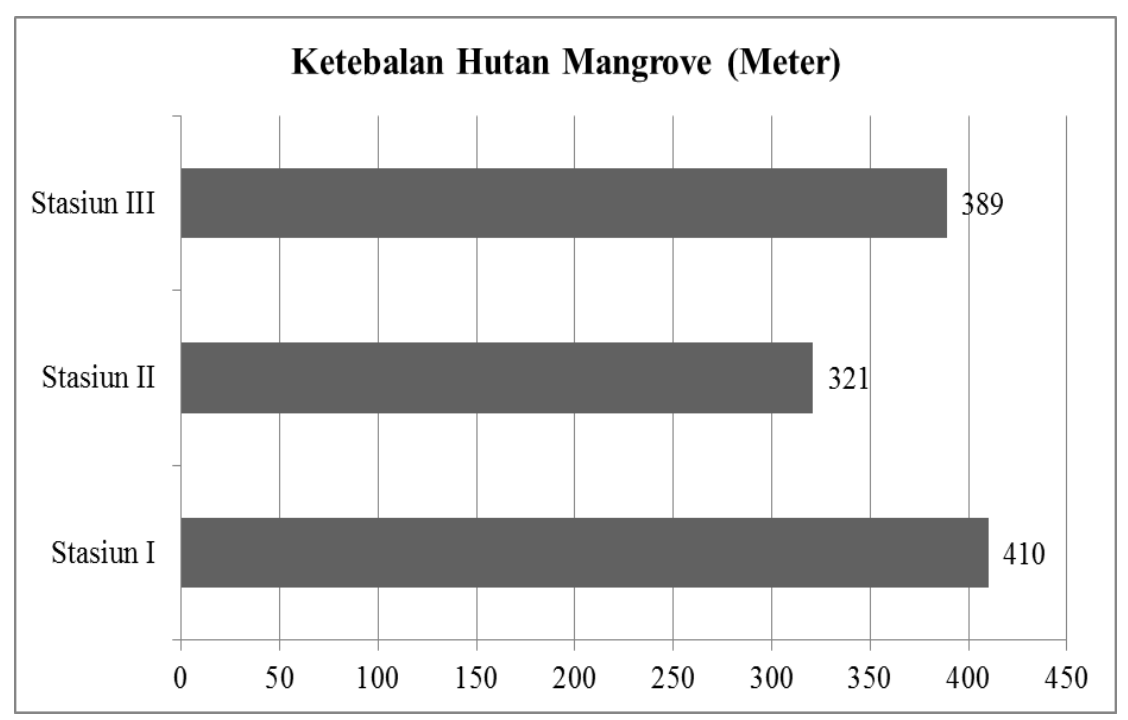

Gambar 2. Ketebalan Hutan Mangrove di Desa Tewe, Kab. Halmahera Barat

\section{Komposisi Jenis Mangrove}

Komposisi jenis hutan mangrove berdasarkan hasil pengamatan pada ketiga stasiun, diperoleh sebanyak 9 jenis dari 5 famili (Tabel 2).

Tabel 2. Komposisi Jenis Mangrove di Desa Tewe

\begin{tabular}{|c|c|c|c|c|}
\hline No & Famili & Spesies & $\begin{array}{c}\text { Nama } \\
\text { Indonesia }\end{array}$ & Nama lokal \\
\hline 1 & Rhizophoraceae & $\begin{array}{l}\text { Rhizophora } \\
\text { stylosa } \\
\text { Rhizophora } \\
\text { apiculata } \\
\text { Rhizophora } \\
\text { mucronata } \\
\text { Ceriops stagal } \\
\\
\text { Bruguiera } \\
\text { qymnorrhiza }\end{array}$ & $\begin{array}{l}\text { Bakau Merah } \\
\text { Bakau } \\
\text { Bakau hitam } \\
\text { Tengar/ M. } \\
\text { Kuning } \\
\text { Tanjang }\end{array}$ & Soki-Soki \\
\hline 2 & Meliaceae & $\begin{array}{l}\text { Xylocarpus } \\
\text { granatum }\end{array}$ & M. Apel/Nyirih & Posi-Posi \\
\hline 3 & Sonneratiaceae & Sonneratia alba & Pedada & Posi-Posi \\
\hline
\end{tabular}




\begin{tabular}{cclcc}
\hline 4 & Avicenniaceae & $\begin{array}{l}\text { Avicennia } \\
\text { marina }\end{array}$ & Pedada & Fika-Fika \\
5 & Myrsinaceae & $\begin{array}{l}\text { Aegiceras } \\
\text { froridum }\end{array}$ & Semak & Soki-Soki \\
\hline
\end{tabular}

Tabel 3. Komposisi Jenis Mangrove di Stasiun I

\begin{tabular}{|c|c|c|c|c|c|}
\hline \multirow{2}{*}{ No } & \multirow{2}{*}{ Jenis } & \multicolumn{3}{|c|}{ Kategori pertumbuhan } & \multirow{2}{*}{ Jumlah } \\
\hline & & Pohon & Anakan & Semaian & \\
\hline 1 & Rhizophora stylosa & 89 & 25 & 17 & 131 \\
\hline 2 & $\begin{array}{l}\text { Rhizophora apiculata } \\
\text { Rhizophora }\end{array}$ & 112 & 22 & 21 & 155 \\
\hline 3 & mucronata & 78 & 19 & 26 & 123 \\
\hline 4 & $\begin{array}{l}\text { Ceriops stagal } \\
\text { Bruguiera }\end{array}$ & 11 & 6 & 2 & 19 \\
\hline 5 & gymnorrhiza & 17 & 3 & 7 & 27 \\
\hline 6 & Xylocarpus granatum & 12 & 5 & 3 & 20 \\
\hline 7 & Avicennia marina & 25 & 5 & 2 & 32 \\
\hline 8 & Sonneratia alba & 11 & 3 & 2 & 16 \\
\hline \multirow[t]{2}{*}{9} & Aegiceras froridum & 18 & 1 & 2 & 21 \\
\hline & & 373 & 72 & 76 & 544 \\
\hline
\end{tabular}

Tabel 4. Komposisi Jenis Mangrove di Stasiun II

\begin{tabular}{|c|c|c|c|c|c|}
\hline \multirow{2}{*}{ No } & \multirow{2}{*}{ Jenis } & \multicolumn{3}{|c|}{ Kategori pertumbuhan } & \multirow{2}{*}{ Jumlah } \\
\hline & & Pohon & Anakan & Semaian & \\
\hline 1 & Rhizophora stylosa & 103 & 12 & 12 & 127 \\
\hline 2 & Rhizophora apiculata & 91 & 17 & 11 & 119 \\
\hline 3 & $\begin{array}{l}\text { Ceriops stagal } \\
\text { Bruguiera }\end{array}$ & 12 & 3 & 1 & 16 \\
\hline 4 & gymnorrhiza & 8 & 3 & 4 & 15 \\
\hline 5 & Avicennia marina & 10 & 2 & 1 & 13 \\
\hline \multirow[t]{2}{*}{6} & Sonneratia alba & 7 & 3 & 2 & 12 \\
\hline & & 231 & 32 & 28 & 302 \\
\hline
\end{tabular}


Tabel 5. Komposisi Jenis Mangrove di Stasiun III

\begin{tabular}{clrrrr}
\hline \multirow{2}{*}{ No } & \multirow{2}{*}{ Jenis } & \multicolumn{3}{c}{ Kategori pertumbuhan } & \multirow{2}{*}{ Jumlah } \\
\cline { 3 - 6 } & & Pohon & Anakan & Semaian & \\
\hline 1 & Rhizophora apiculata & 27 & 11 & 17 & 55 \\
2 & Rhizophora stylosa & 17 & 8 & 14 & 39 \\
3 & Sonneratia alba & 13 & 3 & 2 & 18 \\
4 & Ceriops stagal & 4 & 2 & & 6 \\
& Total & $\mathbf{6 1}$ & $\mathbf{1 9}$ & $\mathbf{3 3}$ & $\mathbf{1 1 8}$ \\
\hline
\end{tabular}

Famili Rhizophoraceae memiliki jumlah jenis lebih banyak yaitu 6 jenis dan famili Avicenniacea, Myrsinaceae, Sonneratiaceae dan Meliaceae memiliki masing-masing 1 jenis (Tabel 2). Banyaknya jenis famili Rhizophoraceae yang ditemukan disebabkan kehadiran jenis ini setiap stasiun dan kuadran lebih banyak, selain itu habibat turut mendukung aspek ekologi, biologi dan fisologi dari famili ini (Tabel 3,4,5) . Jenis famili Rhizophoraceae paling dominanan. Menurut Akbar et al (2015; 2016; 2017) disebabkan peluang ditemukannya jenis dari famili ini tiap kuadran lebih banyak, selain itu habibat turut mendukung aspek ekologi, biologi dan fisologi dari famili ini (Tabel 3,4,5). Karakteristik pulau dengan ciri pantai landai dan luas kearah laut memberikan tempat untuk hidup dan berkembangnya mangrove. Kusmana et al (2003) menyatakan bahwa topografi dapat mempengaruhi komposisi jenis, distribusi jenis dan lebar hutan mangrove.

\section{Struktur Komunitas dan Vegetasi Mangrove}

Struktur vegetasi hutan mangrove menunjukan nilai tertinggi untuk kategori kerapatan terdapat pada stasiun I yakni dengan nilai 30,22 ind/ $\mathrm{m}^{2}$ dan diikuti oleh stasiun II dengan nilai 16,78 ind $/ \mathrm{m}^{2}$ serta nilai terendah terdapat pada stasiun III yaitu $6,56 \mathrm{ind} / \mathrm{m}^{2}$. Kategori frekuensi jenis ditemukan bahwa ditemukan paling tinggi pada stasiun I yakni 4,50 $\mathrm{ind} / \mathrm{m}^{2}$ disusul stasiun II dengan nilai $2,83 \mathrm{ind} / \mathrm{m}^{2}$ dan stasiun III dengan nilai $2,67 \mathrm{ind} / \mathrm{m}^{2}$. Nilai tutupan tertinggi kategori tutupan berada pada stasiun I yaitu 17,09 disusul stasiun II sebesar sebesar 12,49 dan terendah adalah stasiun III dengan nilai 8,05. Sedangkan untuk nilai penting ditemukan nilai rata-rata dari empat stasiun adalah $300 \%$ (Tabel $6)$.

Tingginya nilai kerapatan mangrove pada stasiun I diakibatkan oleh keberadaan substrat yang cocok terhadap pertumbuhan mangrove, selain itu pada lokasi ini aktivitas masyarakat sangat rendah, mangrove dibiarkan tumbuh dan berkembang akibat pemahaman akan pentingnya keberadaan mangrove sebagai habitat ikan dan sumberdaya alam lainya. Sedangkan pada stasiun II dan III ditemukan kebun masyarakat didekat areal mangrove, hal lain yang ditemukan adalah dilokasi tersebut jenis 
mangrove dengan batang yang sudah besar akan diambil dan dibuat bahan untuk rumah kebun masyarakat.

Tabel 6. Struktur Komunitas Hutan Mangrove per Stasiun

\begin{tabular}{cccc}
\hline Jumlah Total & Stasiun 1 & Stasiun 2 & Stasiun 3 \\
\hline Di & $30,22 \mathrm{ind} / \mathrm{m}^{2}$ & $16,78 \mathrm{ind} / \mathrm{m}^{2}$ & $6,56 \mathrm{ind} / \mathrm{m}^{2}$ \\
$\mathrm{Rdi}$ & $100 \%$ & $100 \%$ & $100 \%$ \\
$\mathrm{Fi}$ & $4,50 \mathrm{ind} / \mathrm{m}^{2}$ & $2,83 \mathrm{ind} / \mathrm{m}^{2}$ & $2,67 \mathrm{ind} / \mathrm{m}^{2}$ \\
$\mathrm{Fri}$ & $100 \%$ & $100 \%$ & $100 \%$ \\
$\mathrm{Ci}$ & 17,09 & 12,49 & 8,05 \\
$\mathrm{Rci}$ & $100 \%$ & $100 \%$ & $100 \%$ \\
$\mathrm{NP}$ & $300 \%$ & $300 \%$ & $300 \%$ \\
\hline
\end{tabular}

\section{Indeks Ekologi Mangrove}

Keseluruhan hasil analisis kerapatan relatif, frekuensi, tutupan dan nilai penting jenis setiap lokasi terdapat pada (Tabel 7, 8 dan 9). Kerapatan jenis tertinggi diperoleh pada jenis Rhizophora apiculata, diduga bahwa pada daerah ini memiliki habitat yang cocok, selain itu juga dipengaruhi oleh rendahnya kegiatan pembabatan mangrove dan kemampuan beradaptasi dengan lingkungan. Laporan Akbar et al $(2015 ; 2016 ; 2017 a ; 2017 b)$ menemukan hal yang sama di pesisir Pulau Sidangoli, Pulau Mare, Teluk Dodinga dan Pulau Maitara. Selain itu juga ditemukan Agustini et al (2016) di Desa Kahyapu Pulau Enggano, Sumatera. Kondisi lingkungan lumpur berpasir akan mendukung kehadiran dan merupakan tempat tumbuh berkembang famili Rhizophoraceae (Ernanto et al, 2010; Noor et al, 2012). Kerapatan dari suatu jenis merupakan nilai yang menunjukkan jumlah atau banyaknya individu suatu jenis per satuan luas (Bengen, 2004).

Tabel 7. Struktur Komunitas Hutan Mangrove pada Stasiun I

\begin{tabular}{|c|c|c|c|c|c|c|c|c|}
\hline \multirow{2}{*}{ No } & \multirow{2}{*}{ Jenis } & \multicolumn{7}{|c|}{ Indeks Ekologi } \\
\hline & & Di & Rdi & $\mathbf{F i}$ & Fri & $\mathbf{C i}$ & Rci & NP \\
\hline 1 & $\begin{array}{l}\text { Rhizophora } \\
\text { stylosa } \\
\text { Rhizophora }\end{array}$ & 7,28 & 24,08 & 1,00 & 22,22 & 2,40 & 14,04 & 60,35 \\
\hline 2 & $\begin{array}{l}\text { apiculata } \\
\text { Rhizophora }\end{array}$ & 8,61 & 28,49 & 0,83 & 18,52 & 2,10 & 12,29 & 59,30 \\
\hline 3 & mucronata & 6,83 & 22,61 & 0,50 & 11,11 & 2,20 & 12,87 & 46,59 \\
\hline 4 & Ceriops stagal & 1,06 & 3,49 & 0,50 & 11,11 & 1,20 & 7,02 & 21,63 \\
\hline
\end{tabular}




\begin{tabular}{ccccccccc}
5 & $\begin{array}{l}\text { Bruguiera } \\
\text { gymnorrhiza } \\
\text { Xylocarpus }\end{array}$ & 1,50 & 4,96 & 0,67 & 14,81 & 1,20 & 7,02 & 26,80 \\
6 & $\begin{array}{l}\text { granatum } \\
\text { Avicennia }\end{array}$ & 1,11 & 3,68 & 0,33 & 7,41 & 1,39 & 8,13 & 19,22 \\
7 & $\begin{array}{l}\text { marina } \\
\text { Monneratia }\end{array}$ & 1,78 & 5,88 & 0,33 & 7,41 & 1,80 & 10,53 & 23,82 \\
8 & $\begin{array}{l}\text { Solba } \\
\text { alba }\end{array}$ & 0,89 & 2,94 & 0,17 & 3,70 & 3,50 & 20,48 & 27,12 \\
9 & $\begin{array}{l}\text { Aegiceras } \\
\text { froridum }\end{array}$ & 1,17 & 3,86 & 0,17 & 3,70 & 1,30 & 7,61 & 15,17 \\
\hline & & 30,2 & 100 & 4,5 & 100 & 17,1 & 100 & 300 \\
\hline
\end{tabular}

Tabel 8. Struktur Komunitas Hutan Mangrove pada Stasiun II

\begin{tabular}{|c|c|c|c|c|c|c|c|c|}
\hline \multirow{2}{*}{ No } & \multirow{2}{*}{ Jenis } & \multicolumn{7}{|c|}{ Indeks Ekologi } \\
\hline & & Di & Rdi & $\mathbf{F i}$ & Fri & $\mathbf{C i}$ & Rci & NP \\
\hline \multirow{3}{*}{1} & Rhizophora & & 42,0 & 1,0 & 35,2 & & & 96,5 \\
\hline & stylosa & 7,06 & 5 & 0 & 9 & 2,4 & 19 & 6 \\
\hline & Rhizophora & & 39,4 & 0,8 & 29,4 & & 17,6 & 86,4 \\
\hline 2 & apiculata & 6,61 & 0 & 3 & 1 & 2,2 & 1 & 3 \\
\hline \multirow{3}{*}{3} & Cerione ctagal & & & 0,3 & 11,7 & & & 26,6 \\
\hline & Cerıops stagal & 0,89 & 5,30 & 3 & 6 & 1,2 & 9,61 & 7 \\
\hline & Bruguiera & & & 0,3 & 11,7 & & 11,1 & 27,8 \\
\hline \multirow[t]{2}{*}{4} & gymnorrhiza & 0,83 & 4,97 & 3 & 6 & 1,4 & 3 & 6 \\
\hline & Avicennia & & & 0,1 & & & 14,4 & 24,6 \\
\hline \multirow[t]{2}{*}{5} & marina & 0,72 & 4,30 & 7 & 5,88 & 1,8 & 1 & 0 \\
\hline & Sonneratia & & & 0,1 & & & 28,0 & 37,8 \\
\hline \multirow[t]{3}{*}{6} & alba & 0,67 & 3,97 & 7 & 5,88 & 3,5 & 2 & 8 \\
\hline & & 16,7 & & 2,8 & & 12,4 & & \\
\hline & Total & 8 & 100 & 3 & 100 & 9 & 100 & 300 \\
\hline
\end{tabular}

Keseluruhan hasil menunjukan bahwa jenis mangrove Rhizophora stylosa dan Rhizophora apiculata memiliki peluang atau kesempatan hadir paling tinggi diantara semua jenis mangrove. Hal yang sama juga ditemukan Akbar et al (2015;2016;2017a;2017b) di pesisir Pulau Sidangoli, Pulau Mare, Teluk Dodinga dan Pulau Maitara. Frekuensi jenis menggambarkan kesempatan ataupun kemungkinan dan peluang dapat tumbuh dan ditemukannya suatu spesies dalam suatu areal lokasi yang menjadi areal pengamatan (Akbar et al, 2015). Hutching dan Saenger (2000) kemampuan kompetisi suatu tumbuhan adalah suatu fungsi dari area, aktivitas dan distribusi dalam ruang dan waktu. 
Tabel 9. Struktur Komunitas Hutan Mangrove pada Stasiun III

\begin{tabular}{|c|c|c|c|c|c|c|c|c|}
\hline \multirow{2}{*}{ No } & \multirow{2}{*}{ Jenis } & \multicolumn{7}{|c|}{ Indeks Ekologi } \\
\hline & & Di & Rdi & $\mathbf{F i}$ & Fri & $\mathbf{C i}$ & Rci & NP \\
\hline 1 & $\begin{array}{l}\text { Rhizophora } \\
\text { apiculata }\end{array}$ & $\begin{array}{c}3,0 \\
6\end{array}$ & 46,61 & $\begin{array}{c}1,0 \\
0\end{array}$ & 37,50 & $\begin{array}{c}2,8 \\
7\end{array}$ & 35,65 & 119,76 \\
\hline 2 & $\begin{array}{l}\text { Rhizophora } \\
\text { stylosa }\end{array}$ & $\begin{array}{c}2,1 \\
7\end{array}$ & 33,05 & $\begin{array}{c}0,8 \\
3\end{array}$ & 31,25 & $\begin{array}{c}2,0 \\
1\end{array}$ & 24,97 & 89,27 \\
\hline 3 & Sonneratia alba & $\begin{array}{c}1,0 \\
0\end{array}$ & 15,25 & $\begin{array}{c}0,5 \\
0\end{array}$ & 18,75 & $\begin{array}{c}3,0 \\
5\end{array}$ & 36,65 & 70,65 \\
\hline 4 & Ceriops stagal & $\begin{array}{c}0,3 \\
3\end{array}$ & 5,08 & $\begin{array}{c}0,3 \\
3\end{array}$ & 12,50 & $\begin{array}{c}0,2 \\
2\end{array}$ & 2,73 & 20,32 \\
\hline & Total & $\begin{array}{c}6,5 \\
6 \\
\end{array}$ & 100 & $\begin{array}{c}2,6 \\
7 \\
\end{array}$ & 100 & $\begin{array}{c}8,0 \\
5\end{array}$ & 100 & 300 \\
\hline
\end{tabular}

Nilai penutupan tertinggi pada setiap stasiun diperoleh Soneratia alba (Tabel 7, 8 dan 9). Hal yang sama juga ditemukan Akbar et al (2015; 2016; 2017a; 2017b) di pesisir Pulau Sidangoli, Pulau Mare, Teluk Dodinga dan Pulau Maitara. Tutupan jenis tertinggi disebabkan karena ukuran lingkar batang yang besar dengan tutupan kanopi yang tinggi. Karakterisktik dan kriteria ini ditemukan pada jenis mangrove Sonneratia alba. Secara keseluruhan penutupan jenis tertinggi setiap stasiun ditemukan pada Soneratia alba. Hal ini sangat berhubungan erat dengan lingkar batang pohon (Akbar et al., 2015). Indeks nilai penting menunjukan bahwa jenis dari famili Rhizophoraceae memiliki nilai paling tinggi, kemudian Famili Sonneratiaceae. Komposisi dan jumlah kehadiran tiap individu pada lokasi penelitian memberikan pengaruh terhadap nilai penting. Selain itu menunjukan bahwa famili ini sangat mendominasi setiap lokasi, dengan nilai kerapatan, tutupan dan kehadiran jenis yang tinggi. Aktivitas pemanfaatan untuk jenis ini pada lokasi penelitian sangatlah kurang, dikarenakan masyarakat sudah menyadari pentingnya kehadiran mangrove dilingkungan sekitar. habitat yang cocok dan kondisi perairan yang stabil adalah faktor-faktor yang dapat mempengaruhi besarnya nilai penting (Akbar et al, 2015).

Analisis keanekaragaman jenis mangrove setiap stasiun menunjukan bahwa stasiun I 1,82 yakni 1,30, pada stasiun II ditemukan keanekaragaman bernilai 1,30, kemudian stasiun III memiliki nilai rendah yakni 1,16 (Gambar 04). Berdasarkan kriteria keanekaragaman jenis, maka ketiga stasiun masuk dalam kriteria keanekaragaman sedang. Penelitian dengan hasil yang sama juga ditemukan Mukhlisi et al (2013) di Desa Sidodadi Kecamatan Padang Cermin Kabupaten Pesawaran, Provinsi Lampung. Kemudian Akbar et al (2017a), Teluk Dodinga, Kabupaten Halmahera Barat. Provinsi Maluku Utara. Selain itu Agustini et al (2016) juga dimana tingkat keanekaragaman jenis mangrove masuk dalam kategori sedang di Pulau Enggano. Laporan yang berbeda ditemukan Akbar et al (2016 dan 2017b) di Pulau Mare dan Pulau Maitara, 
Kota Tidore Kepulauan dimana keanekakaragaman pada daerah ini rendah. Indriyanto (2006) keanekaragaman jenis juga dapat digunakan untuk mengukur stabilitas komunitas, yaitu kemampuan suatu komunitas untuk menjaga dirinya tetap stabil. Nilai keanekaragaman yang diperoleh memperlihatkan adanya variasi antar stasiun, hal ini disebabkan karena komposisi dan jumlah jenis yang ditemukan setiap lokasi berbeda-beda. Nilai keanekaragaman yang diperoleh memperlihatkan adanya variasi antar stasiun, hal ini karena komposisi dan jumlah jenis yang ditemukan setiap lokasi berbeda. Faktor lain mempengaruhi keanekaragaman jenis dan pertumbuhan mangrove adalah suplai air tawar dari sungai yang bermuara ke laut, kesesuaian habitat pada iklim dan kondisi geografis (Duke et al, 1998). Tinggi rendahnya keanekaragaman juga dipengaruhi oleh aktivitas antropogenik yang terjadi. Masyarakat Desa Tewe sering memanfaatkan mangrove sebagai kayu bakar, bahan bangunan rumah tepi pantai dan sebagai tiang jembatan serta tempat menjaring ikan.

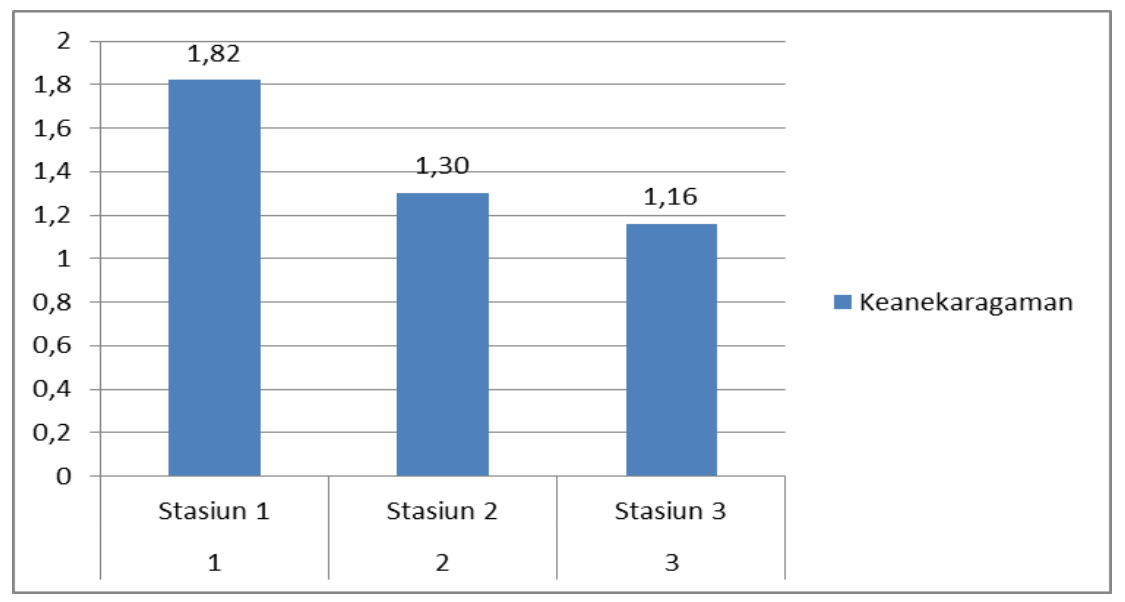

Gambar 3. Keanekaragaman Mangrove per Stasiun

Nilai indeks keanekaragaman spesies mangrove pada setiap stasiun, diperoleh nilai keanekaragaman spesies tertinggi pada stasiun I dari 9 spesies yang ditemukan adalah Rhizophora apiculata dengan nilai 0,36 kemudian Rhizophora stylosa dan Rhizophora mucronata yaitu 0,34 dan terendah Ceriops stagal yakni 0,12 (Gambar 4). Pada stasiun II ditemukan 6 spesies dengan keanekaragaman tertinggi diperoleh Rhizophora apiculata sebesar 0,37, kemudian Rhizophora stylosa dengan nilai 0,36 diikuti Ceriops stagal yakni 0,16 dan keanekaragaman spesies terendah ditemukan pada Sonneratia alba yaitu 0,13 (Gambar 5). Sedangkan untuk stasiun III keanekaragaman tertinggi dari dari 4 spesies yang ditemukan diperoleh Rhizophora stylosa sebesar 0,37, diikuti Rhizophora apiculata dengan nilai 0,36 kemudian terendah pada spesies Ceriops stagal yaitu 0,15 (Gambar 6). 


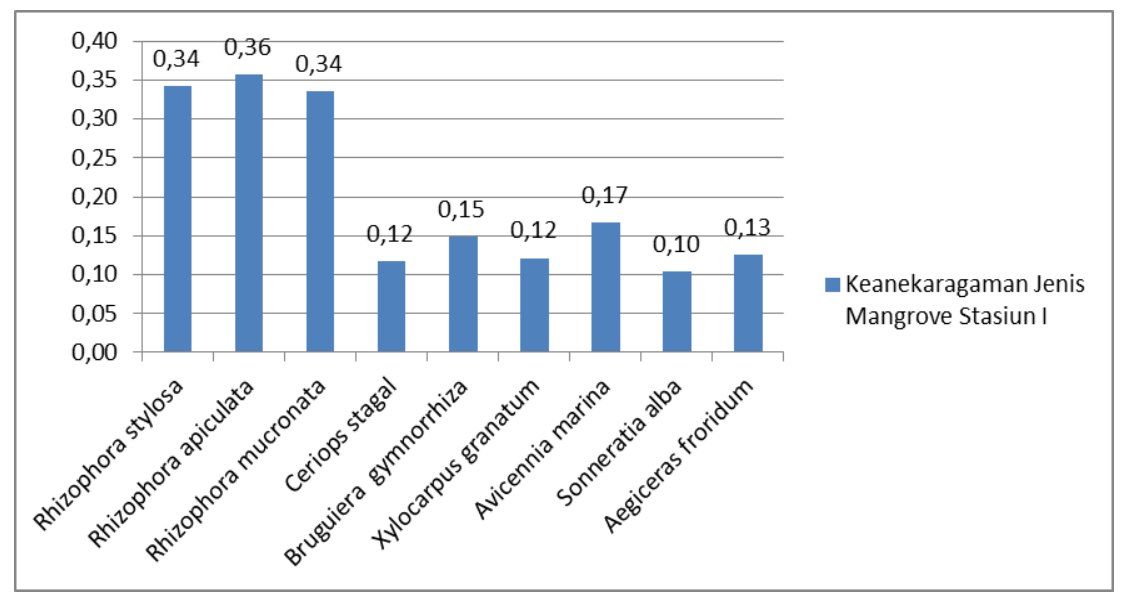

Gambar 4. Keanekaragaman Spesies Mangrove Stasiun I

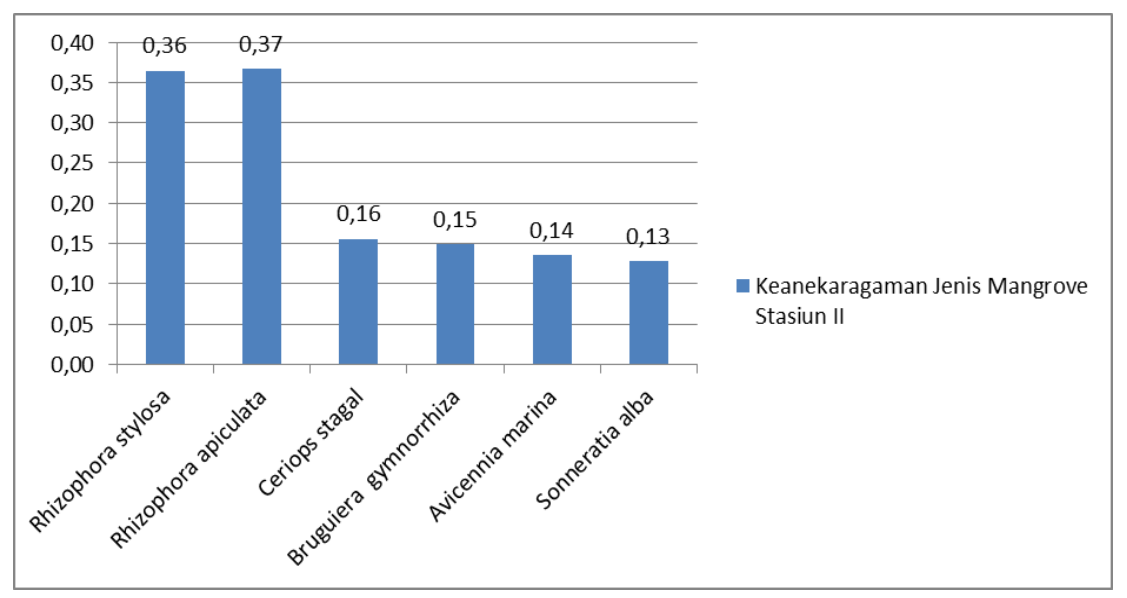

Gambar 5. Keanekaragaman Spesies Mangrove Stasiun II

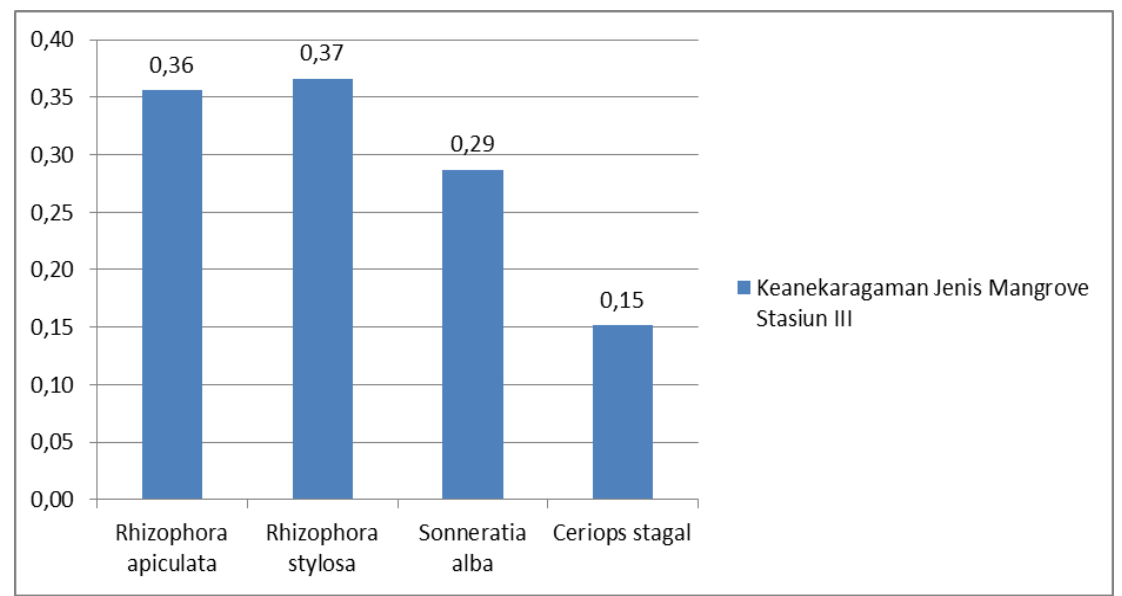

Gambar 6. Keanekaragaman Spesies Mangrove Stasiun III

Hasil penelitian yang sama di peroleh Akbar et al (2017a) yang menemukan keanekaragaman di Teluk Dodinga masuk dalam kategori 
sedang. Nilai indeks keanekaragaman jenis mangrove ini sedikit lebih tinggi dari Pulau Sebatik, Kalimantan Timur dengan $H^{\prime}=0,64-1,55$ (Ardiansyah et al, 2012) dan kawasan hutan mangrove di Banyuasin, Sumatera Selatan dengan $H^{\prime}=0,34-0,88$ (Indriani et al, 2009). Selain itu Akbar et al (2016; 2017b) memperoleh nilai keanekaragaman jenis yang rendah pada Pulau Mare dan Maitara. Nilai keanekaragaman suatu komunitas sangat bergantung pada jumlah jenis dan jumlah individu yang terdapat pada komunitas tersebut.

\section{KESIMPULAN}

Kehadiran jenis mangrove dilokasi ini sangat tinggi yakni 9 spesies dari 5 famili. Kondisi perairan masih mendukung kehadiran dan pertumbuhan mangrove. Hasil analisis menunjukan struktur komunitas hutan mangrove di Desa Tewe berdasarkan indeks ekologi (nilai kerapatan, frekuensi jenis, tutupan dan nilai penting) cukup baik, sedangkan keanekaragaman spesies mangrove termasuk dalam kategori sedang. Akan tetapi aktivitas pemanfaatan teluk perlu mendapatkan perhatian khusus., sehingga kelestarian dan kehadiran mangrove tetap terjaga. Selain itu perlu suatu pendekatan pada masyarakat untuk membantu memberikan informasi terhadap peran, manfaat dan juga strategi pengelolaan serta pelestarian mangrove kedepan.

\section{UCAPAN TERIMA KASIH}

Penulis mengucapkan terimakasih kepada Fakultas Perikanan dan IImu Kelautan atas dana hibah mandiri yang diberikan untuk penelitian ini. Selain itu juga kepada aparatur dan masyarakat Desa Tewe yang bersedia membantu penulis selama penelitian. 


\section{DAFTAR PUSTAKA}

Agustini N.T, Ta'alidin Z dan Purnama D. 2016. Struktur Komunitas Mangrove Di Desa Kahyapu Pulau Enggano. Jurnal Enggano, Vol 1, No $1: 19-31$

Akbar, N., Baksir, A.,Tahir, I. 2015. Struktur Komunitas Ekosistem Mangrove di Kawasan Pesisir Sidangoli Kabupaten Halmahera Barat, Maluku Utara. Depik Jurnal, Vol 4, No 3 : 132-143.

Akbar, N., A. Baksir, Tahir I, Arafat D. 2016. Struktur komunitas mangrove di Pulau Mare, Kota Tidore Kepulauan, Provinsi Maluku Utara. Depik, Vol 5, No 3: 133-142.

Akbar N, Marus I, Haji I, Abdullah S, Umalekhoa S, Ibrahim1 F.S., Ahmad M, Ibrahim A, Kahar A, dan Tahir I. 2017a. Struktur Komunitas Hutan Mangrove Di Teluk Dodinga, Kabupaten Halmahera Barat Provinsi Maluku Utara. Jurnal Enggano, Vol 2, No 1 : 78-89

Akbar N, Haya N, Baksir A, Harahap Z.A, Tahir I, Ramili Y, Kotta R.2017b. Struktur komunitas dan pemetaan ekosistem mangrove di pesisir Pulau Maitara, Provinsi Maluku Utara, Indonesia. Depik jurnal, Vol 6, No $2: 167-181$

Aksornkoae S. 1993. Ecology and Management of Mangroves. Bangkok: IUCN

Ardiansyah, W.I, R. Pribadi \& S. Nirwan. 2012. Struktur dan komposisi vegetasi mangrove di kawasan pesisir Pulau Sebatik, Kabupaten Nunukan, Kalimantan Timur. Journal of Marine Research, Vol 1, No 2 : 203-215

Asman, 2007. Studi Pemetaan Ekosistem Hutan Mangrove di Pesisir Pantai Desa Sidangoli Dehe Kecamatan Jailolo Selatan Kabuopaten Halmahera Barat Provinsi Maluku Utara. Skripsi. Jurusan IImu Kelautan. Fakultas Perikanan dan IImu Kelautan Universitas Khairun. Ternate.

Balai Pengelolaan Daerah Aliran Sungai (Bapedas) Ake Malamo. 2010. Buku IV (naskah dan data). Rencana teknik rehabilitasi hutan dan lahan daerah aliran sungai (RTk-RHL DAS) ekosistem mangrove dan sempadan pantai wilayah kerja bpdas ake malamo. Ternate.

Bengen, D. G., 2004. Pedoman Teknis Pengenalan dan Pengelolaan Ekosistem mangrove. Pusat Kajian Sumberdaya Pesisir Dan Lautan. IPB. Bogor. 
Duke, N.C., M C. Ball and J.C. Ellison. 1998. Factors influencing biodiversity and distributional gradients in mangroves. Global Ecology and Biogeography Letters, Vol 7, No 1: 27-47.

Ernanto, R., F. Agustriani, R. Aryawati. 2010. Struktur komunitas gastropoda pada ekosistem mangrove di muara Sungai Batang Ogan Komering llir Sumatera Selatan. Maspari Journal, 01:73-78.

Hakim, N. 2009. Penuntun Ringkas Dasar - Dasar Ilmu Tanah. Universitas Andalas: Padang.

Hutching, P., P. Saenger. 2000. Ekologi mangrove. Laboratorium Ekologi Hutan. Fakultas Kehutanan Institut Pertanian Bogor.Bogor

Indriyanto, 2006. Ekologi Hutan. Jakarta: Penerbit PT Bumi Aksara

Indriani, D.P, H. Marisa \& Zakaria. 2009. Keanekaragaman spesies tumbuhan pada kawasan mangrove Nipah (Nypa fruticans Wurmb.) di Kec. Pulau Rimau Kab. Banyuasin Sumatera Selatan. Jurnal Penelitian Sains, Vol 12, No $3: 1-4$

Krebs, C. J. 1985. Experimental Analysis of Distrbution of Abudance. Thrid edition. New York: Harper \& Row Publisher

Mukhlisi, IGN. B,H, Hartuti P. 2013. Keanekaragaman Jenis dan Struktur Vegetasi Mangrove di Desa Sidodadi Kecamatan Padang Cermin Kabupaten Pesawaran, Provinsi Lampung. Prosiding Seminar Nasional Pengelolaan Sumberdaya Alam dan Lingkungan 2013

Muryani C. 2009. Analisis Faktor-Faktor Lingkungan Hutan Mangrove Pantai Pasuruan. Jurnal Geografi, Vol 8, No $1: 1113-1127$

Kusmana, C dan Istomo. 1995. Ekologi Hutan. Laboratorium Kehutanan. Fakultas Kehutanan. Intitut Pertanian Bogor. Bogor.

Kusmana, C., S. Wilarso, I. Hilwan, P. Pamoengkas, C. Wibowo, T. Tiryana, A. Triswanto, Yunasfi, Hamzah, 2003. Teknik Rehabilitasi Mangrove. Fakultas Kehutanan IPB. Bogor. 177 Hal.

Noor, Y. R., M. Khazali, I. N. N. Suryadiputra. 2012. Panduan pengenalan mangrove di Indonesia. Cetakan ke-3. Bogor: Wetlands International Indonesia Programme.

Odum, E. P. 1971. Fundanental Of Ecology third Edition. W. B. Sounder Compan, Philadelphia. USA. 
Saru, A. 2009. Konstibusi Parameter Oseanografi Fisika Terhadap Distribusi Mangrove di Muara Sungai Pangkajene. J. Sains \& Teknologi, Vol 9 No.3 : 210- 217

Setiawan H. 2013. Status Ekologi Hutan Mangrove Pada Berbagai Tingkat Ketebalan. Jurnal Penelitian Kehutanan Wallacea, Vol 2, No 2 : 104 $-120$

Tarigan, M. S. 2008. Sebaran Dan Luas Hutan Mangrove Di Wilayah Pesisir Teluk Pising Utara Desa Kabaena Provinsi Sulawesi Tenggara. Makara, Sains, Vol 12, No. $2: 108-112$.

Yunus, Abd. Haris, 2007. Pengukuran Potensi Hutan Mangrove di Desa Gam Kecamatan Jailolo Selatan Kabupaten Halmahera Barat. Skripsi. Jurusan Manajemen Sumberdaya Perairan. Fakultas Perikanan dan Ilmu Kelautan Universitas Khairun. Ternate. 